\title{
Spatiotemporal distribution of light-absorbing carbon and its relationship to other atmospheric pollutants in Stockholm
}

\author{
P. Krecl ${ }^{1, *}$, A. C. Targino ${ }^{2}$, and C. Johansson ${ }^{1,3}$ \\ ${ }^{1}$ Department of Applied Environmental Science, Atmospheric Science Unit, Stockholm University, Stockholm, Sweden \\ ${ }^{2}$ Universidade Tecnológica Federal do Paraná, Londrina, Brazil \\ ${ }^{3}$ Stockholm Environment and Health Administration, Stockholm, Sweden \\ *now at: the School of Earth and Environment, University of Leeds, Leeds, UK
}

Received: 19 February 2011 - Published in Atmos. Chem. Phys. Discuss.: 29 April 2011

Revised: 9 November 2011 - Accepted: 11 November 2011 - Published: 21 November 2011

\begin{abstract}
Carbon-containing particles have deleterious effects on both Earth's climate and human health. In Europe, the main sources of light-absorbing carbon (LAC) emissions are the transport (67\%) and residential (25\%) sectors. Information on the spatiotemporal variability of LAC particles in urban areas is relevant for air quality management and to better diagnose the population exposure to these particles. This study reports on results of an intensive field campaign conducted at four sites (two kerbside stations, one urban background site and a rural station) in Stockholm, Sweden, during the spring 2006. Light-absorbing carbon mass $\left(\mathrm{M}_{\mathrm{LAC}}\right)$ concentrations were measured with custom-built Particle Soot Absorption Photometers (PSAP). The spatiotemporal variability of $\mathrm{M}_{\mathrm{LAC}}$ concentrations was explored by examining correlation coefficients $(R)$, coefficients of divergence (COD), and diurnal patterns at all sites. Simultaneous measurements of $\mathrm{NO}_{\mathrm{x}}, \mathrm{PM}_{10}, \mathrm{PM}_{2.5}$, and meteorological variables were also carried out at the same locations to help characterize the LAC emission sources.

Hourly mean ( \pm standard deviation) $\mathrm{M}_{\mathrm{LAC}}$ concentrations ranged from $0.36 \pm 0.50$ at the rural site to $5.39 \pm 3.60 \mu \mathrm{g} \mathrm{m} \mathrm{m}^{-3}$ at the street canyon site. Concentrations of LAC between urban sites were poorly correlated even for daily averages $(R<0.70)$, combined with highly heterogeneously distributed concentrations (COD $>0.30$ ) even at spatial scales of few kilometers. This high variability is connected to the distribution of emission sources and processes contributing to the LAC fraction at these sites. At urban sites, $\mathrm{M}_{\mathrm{LAC}}$ tracked $\mathrm{NO}_{\mathrm{x}}$ levels and traffic density well and mean $\mathrm{M}_{\mathrm{LAC}} / \mathrm{PM}_{2.5}$ ratios were larger (26-38\%) than at the background sites
\end{abstract}

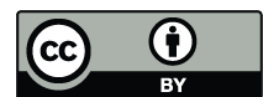

Correspondence to: P. Krecl (p.krecl@leeds.ac.uk)
(4-10\%). The results suggest that vehicle exhaust emissions are the main responsible for the high $\mathrm{M}_{\mathrm{LAC}}$ concentrations found at the urban locations whereas long-range transport (LRT) episodes of combustion-derived particles can generate a strong increase of levels at background sites.

To decrease pollution levels at kerbside and urban background locations in Stockholm, we recommend abatement strategies that target reductions of vehicle exhaust emissions, which are the main contributors to $\mathrm{M}_{\mathrm{LAC}}$ and $\mathrm{NO}_{\mathrm{x}}$ concentrations.

\section{Introduction}

Primary carbonaceous particles are mostly emitted by combustion processes (transport, residential sector, industry, and power generation) and represent a large fraction of the submicron aerosol. Regarding the optical properties of the carbonaceous material, it is usually described as two major constituents: light-absorbing carbon (LAC), with strong absorption of visible light, and organic carbon (OC), with weak absorption in the visible electromagnetic spectrum. Despite the detrimental effect of carbon-containing particles on human health (Lighty et al., 2000; Franco Suglia et al., 2007) and the potential of the LAC fraction to modify the radiative budget regionally (Ramanathan et al., 2007) and to have other adverse effects on climate (e.g. Ramanathan et al., 2001; Ackerman et al., 2000; Menon et al., 2002), their emission and ambient concentrations are still not addressed by local regulations worldwide.

The main emission sources of LAC in Europe are road transport $(49 \%)$, residential combustion of solid fuels ( $25 \%$ ), and off-road transport (18\%) according to estimations by Kupiainen and Klimont (2007) for the year 2000.

Published by Copernicus Publications on behalf of the European Geosciences Union. 
In Sweden, the main sources contributing to LAC emissions are road transport (37\%), residential combustion of biofuels $(25 \%)$, and off-road transport (23\%) as extracted from the Bond et al. (2004) global inventory based on 1996 fuel-use data. Streets et al. (2004) projected a reduction of LAC emissions in Europe in 2030 and 2050 (36-64\% depending on the IPCC scenario), mainly due to the introduction of advanced vehicle technology. A $40 \%$ decrease of LAC emissions is predicted in Sweden for the year 2020 compared to 2007, associated to more stringent particulate emission standards for diesel engines and other vehicles (R. Abrahamsson, personal communication, 2011). However, advances in reducing atmospheric emissions by the development of cleaner vehicle technologies could be balanced or even exceeded by increasing traffic density in many cities.

Compared to rural zones, urban areas are characterized by higher population density, larger number of pollutant emission sources, higher atmospheric pollutants concentrations, and a higher LAC content in the fine particle $\left(\mathrm{PM}_{2.5}\right)$ fraction (Putaud et al., 2004). Simultaneous and continuous timeresolved LAC measurements are required in different parts of the city to (1) characterize the carbon-containing particle sources which can be used to streamline successful air quality control strategies to safeguard public health, (2) understand the particles fate and transport in the urban atmosphere, (3) study the spatiotemporal variability of LAC particles to better diagnose the population exposure to these particles, and (4) determine to what extent the limit values for $\mathrm{PM}_{2.5}$ and $\mathrm{PM}_{10}$ regulate the LAC concentrations, since LAC would be a good candidate substance to be regulated if both climate and health effects of emissions are to be considered.

Stockholm is the largest metropolitan region in Scandinavia (1.25 million inhabitants in the urban area) and has an extensive air quality monitoring program created by the Stockholm Environment and Health Administration and operated by SLB analys. For several atmospheric pollutants (carbon monoxide, sulphur dioxide, benzene, lead, and benzo[a]pyrene) Stockholm concentrations are below the national environmental quality standards (which are the same as the EU directives) even on the busiest streets in the inner city (Johansson et al., 2009). However, nitrogen dioxide $\left(\mathrm{NO}_{2}\right)$ and $\mathrm{PM}_{10}$ mass concentrations still exceed the air quality standards (annual mean limit value of $40 \mu \mathrm{g} \mathrm{m}^{-3}$ ) in Stockholm city in connection to high traffic emissions (Johansson et al., 2009). High $\mathrm{PM}_{10}$ concentrations are found in the inner city in springtime mostly due to particle resuspension, as a result of the use of studded tires when roads are free from snow (Norman and Johansson, 2006). While the spatial variability of particle mass concentrations (Johansson et al., 2007a) and particle number concentrations (Gidhagen et al., 2004a; 2004b; 2005) over Stockholm has already been assessed in previous studies, considerably less is known about the distribution of LAC particles within the city (Johansson et al., 2007b) and the relationship between the LAC particle fraction and other atmospheric pollutants.

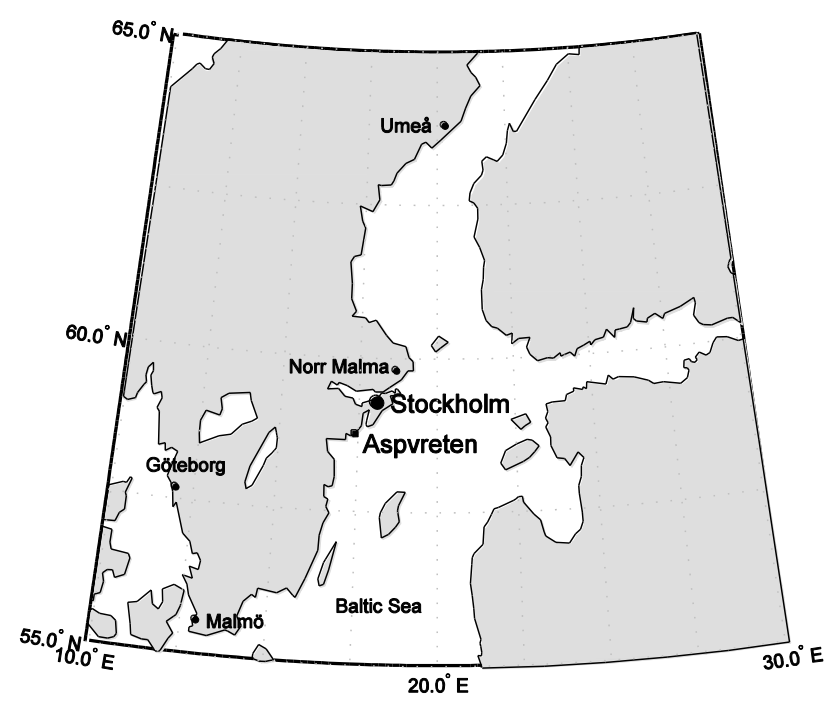

Fig. 1. Location of Stockholm city, Aspvreten and Norr Malma rural background sites.

This work investigates the spatiotemporal variation of hourly light-absorbing carbon concentrations in Stockholm city in springtime. First, the performance of the custombuilt instruments is evaluated in ambient air by comparing their measurements with those from commercial instruments. Then, descriptive statistics are presented for different monitoring sites and the spatial and temporal variation of the LAC mass $\left(\mathrm{M}_{\mathrm{LAC}}\right)$ concentrations is also examined. To help characterize the LAC emission sources, we also report the relationships between LAC and other atmospheric pollutants $\left(\mathrm{PM}_{2.5}, \mathrm{PM}_{10}\right.$, and $\left.\mathrm{NO}_{\mathrm{x}}\right)$, the diurnal cycles of these pollutants, and the wind dependence of the concentrations. Finally, the urban and rural contributions to the atmospheric pollutants load are discussed.

\section{Description of measurement sites}

An intensive field study was conducted simultaneously at three monitoring sites in central Stockholm (Hornsgatan, Torkel Knutssonsgatan (referred to as "Torkel"), and Essingeleden) and at a rural station (Aspvreten) in spring 2006 (Figs. 1 and 2). Hornsgatan is a four-lane $24 \mathrm{~m}$ wide street canyon with $24 \mathrm{~m}$ high buildings. Instruments were housed in a trailer parked on the street with a traffic volume of $\sim 28000$ vehicles per day. On average, the composition of the vehicle fleet is: passenger cars $77 \%$, light-duty vehicles $12 \%$, buses $2 \%$, and heavy-duty vehicles $1 \%$. Half of the vehicle fleet runs on gasoline, $30 \%$ uses diesel ( $21 \%$ of the passenger cars, most of the taxis and heavy-duty vehicles), and $14 \%$ are ethanol vehicles ( $80 \%$ of the buses and $15 \%$ of the passenger cars) (Burman and Johansson, 2010). Torkel is located on a rooftop platform ( $25 \mathrm{~m}$ height) and thereby represents urban background concentrations for the Stockholm 


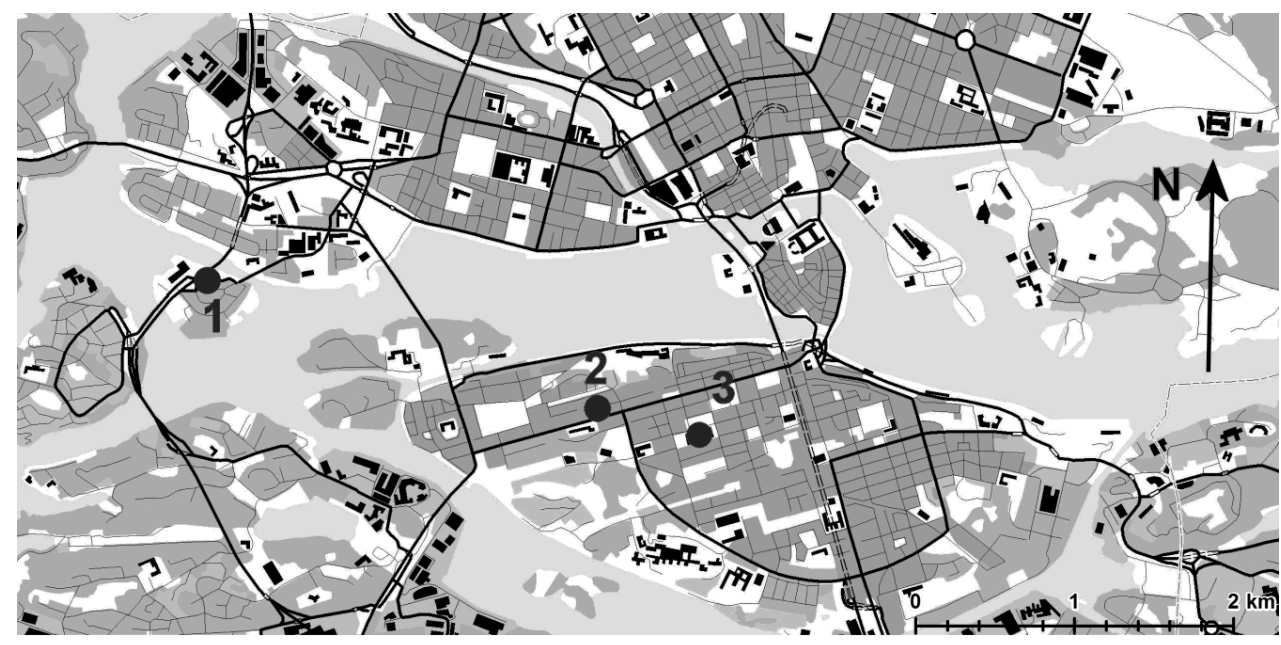

Fig. 2. Location of the monitoring stations in Stockholm: Essingeleden (1), Hornsgatan (2), and Torkel (3). Blue indicates water surfaces, green forest/park areas, orange built-up areas, black lines important roads, and grey represent public buildings (e.g., hospitals, museums, schools).

region, since it is not directly affected by nearby atmospheric emissions. Measurements were also carried out near Essingeleden, on the island of Lilla Essingen, by the kerb of the eight-lane E4 highway with a traffic flow of $\sim 128000$ vehicles per day. The distance between Hornsgatan and Torkel sites is $450 \mathrm{~m}$, Hornsgatan-Essingeleden distance is $2.7 \mathrm{~km}$, and Torkel and Essingeleden sites are $3.1 \mathrm{~km}$ apart. Aspvreten is a rural background station operated by ITM and is part of two European-scale aerosol monitoring networks: the European Monitoring and Evaluation Programme (EMEP) and the European Supersites for Atmospheric Aerosol Research (EUSAAR). The station is located $80 \mathrm{~km}$ southwest of Stockholm and $2 \mathrm{~km}$ inland from the Baltic Sea, and surrounded by deciduous and coniferous forest and grasslands. Measurements conducted at Norr Malma rural background station, located in a rural area $\sim 70 \mathrm{~km}$ northeast of Stockholm and $1 \mathrm{~km}$ south of Lake Erken (Fig. 1), were used to complete or complement Aspvreten data.

\section{Instrumentation and sampling program}

\subsection{Carbonaceous aerosol}

Measurements of light-absorbing carbon were performed using custom-built Particle Soot Absorption Photometers (PSAP) at the four sites (central Stockholm and Aspvreten) and two commercial Aethalometers installed at Hornsgatan and Torkel. The measurement principle of these instruments is the same and relies on the light absorbing properties of the carbonaceous aerosols. The method is based on the integrating plate technique (Lin et al., 1973) that measures the attenuation of light transmitted through particles that are continuously collected on a filter. The LAC mass absorption cross section $\sigma_{\mathrm{a}}$ relates the absorption coefficient of the aerosol $b_{\mathrm{ap}}$ to the $\mathrm{M}_{\mathrm{LAC}}$ concentration. The calculation of $\sigma_{\mathrm{a}}$ requires the determination of $\mathrm{M}_{\mathrm{LAC}}$ by an independent method (e.g., thermo-optical measurements).

The Aethalometers series 8100 (Magee Scientific, USA) were operated with $\mathrm{PM}_{2.5}$ sample inlets (installed at $3.5 \mathrm{~m}$ above ground level) and a sample flow rate of $21 \mathrm{~min}^{-1}$. The instruments reported 1-min values, calculated from 5min moving averages, and 15 -min average values were logged into the acquiring system. Aethalometer concentrations were computed using the $\sigma_{\mathrm{a}}$ value provided by the manufacturer $\left(16.6 \mathrm{~m}^{2} \mathrm{~g}^{-1}\right)$. In this study, mean offset values of $0.50 \mu \mathrm{g} \mathrm{m}^{-3}$ and $0.21 \mu \mathrm{g} \mathrm{m}^{-3}$ were subtracted from Aethalometer $\mathrm{M}_{\mathrm{LAC}}$ concentrations measured at Hornsgatan and Torkel, respectively. These offset values were found when operating the Aethalometer in the field with particlefree air drawn through the filter for several days. Similar Aethalometer offset values were observed by the instrument supplier when running baseline measurements (Krecl et al., 2007).

The custom-built PSAPs were constructed at ITM, Stockholm University (herein after referred to as PSAP-ITM) and a detailed description can be found in Krecl et al. (2007; 2010). For this campaign, sample inlets were installed at $\sim 2 \mathrm{~m}$ above ground level and no pre-cut size devices were used. The PSAP particle sampling was conducted through $1 / 4^{\prime \prime}$ stainless steel tubing with the flow rate controlled by a needle valve $\left(\sim 0.061 \mathrm{~min}^{-1}\right.$ at central Stockholm sites, and $0.21 \mathrm{~min}^{-1}$ at the rural site). Data were logged every $30 \mathrm{~s}$ and a 4-min moving average was computed for all voltages prior to calculating the absorption coefficients. Several corrections were applied to PSAP measurements, as described in Krecl et al. $(2007 ; 2010)$, to obtain the absorption 
coefficient of the airborne particles: filter property correction, filter loading correction, scattering correction and additional absorption correction. To correct for aerosol light scattering aerosol deposited onto the PSAP filter, two approaches were used depending on the data availability at each site: (1) aerosol scattering coefficient measurements performed at Hornsgatan in the period 23 May-6 July 2006 using an integrating nephelometer $(520 \mathrm{~nm}$ wavelength, model M9003, Ecotech, Australia), (2) aerosol light-scattering coefficients estimated from $\mathrm{PM}_{2.5}$ mass measurements multiplied by the aerosol mass scattering coefficient (Krecl et al., 2007). For the urban sites, the mass scattering coefficient was obtained when linearly correlating daily mean $\mathrm{PM}_{2.5}$ and aerosol light scattering measurements at Hornsgatan in the period 23 May-30 August 2006 (slope of $4.0 \pm 0.37$ (95\% confidence interval), correlation coefficient $R=0.92$, number of samples: 99). Essingeleden $\mathrm{PM}_{2.5}$ measurements were used in these calculations when Hornsgatan data were missing. Finally, a mass scattering coefficient of $4.0 \mathrm{~m}^{2} \mathrm{~g}^{-1}$ was used to correct all Stockholm PSAP calculations which agrees well with reported values for polluted continental air $\left(3.5 \pm 1.2 \mathrm{~m}^{2} \mathrm{~g}^{-1}\right.$, IPCC, 2001). In the case of Aspvreten, a mass scattering coefficient of $2.0 \mathrm{~m}^{2} \mathrm{~g}^{-1}$ was taken from the literature for rural background conditions (IPCC, 2001; Pereira et al., 2008) and $\mathrm{PM}_{2.5}$ concentrations were estimated as $80 \%$ of $\mathrm{PM}_{10}$ levels (Areskoug et al., 2004) when $\mathrm{PM}_{2.5}$ data were missing.

Finally, to convert the aerosol light absorption coefficient into $\mathrm{M}_{\mathrm{LAC}}$ we assumed that all light absorption was from light-absorbing carbon and that all LAC had the same mass absorption cross section at each site over the sampling period. In situ $\sigma_{\mathrm{a}}$ values were determined by linearly correlating aerosol light-absorption coefficients (after applying all corrections) with elemental carbon (EC) mass concentrations. For EC/OC analysis, quartz fiber filters were collected at Torkel and Aspvreten using a $10 \mu \mathrm{m}$ cut-off size sequential sampler (model SEQ 47/50, Leckel GmbH, Germany) installed at $1.6 \mathrm{~m}$ above rooftop level operated at a standard flow rate of $38.31 \mathrm{~m}^{-1}$. Filters were pre-baked in a furnace at $800^{\circ} \mathrm{C}$ for $150 \mathrm{~min}$ and placed in clean glass Petri dishes and kept refrigerated before and after the filter sampling. The EC/OC analysis was carried out using a Thermal/Optical Carbon Aerosol Analyzer (Sunset Laboratory Inc., Forest Grove, USA) operating on the NIOSH method 5040 (Birch and Cary, 1996). Mass specific absorption cross sections of $7.6 \mathrm{~m}^{2} \mathrm{~g}^{-1}(R=0.80$, number of samples: 9) and $10 \mathrm{~m}^{2} \mathrm{~g}^{-1}(R=0.90$, number of samples: 10$)$ were obtained at Torkel and Aspvreten, respectively. The $\sigma_{\mathrm{a}}$ value for Torkel is in agreement with freshly generated light-absorbing carbon values $\left(7.5 \pm 1.2 \mathrm{~m}^{2} \mathrm{~g}^{-1}\right)$ summarized by Bond and Bergstrom (2005) at a wavelength of $550 \mathrm{~nm}$ and was used for all Stockholm sites. The Aspvreten value is typical of aged LAC aerosol at background sites (Cozic et al., 2008).

\subsection{Other measurements}

$\mathrm{PM}_{10}$ and $\mathrm{PM}_{2.5}$ mass measurements were performed at all sites using automatic Tapered Element Oscillating Microbalance (TEOM 1400a, Rupprecht \& Patashnick Inc., USA) instruments with heated inlets $\left(50^{\circ} \mathrm{C}\right)$ to avoid condensing water. To account for losses of volatile material on the particles, all TEOM data were corrected following Areskoug (2007). In short, built-in TEOM corrections were removed, mass concentrations were expressed at ambient pressure and temperature and, finally, concentrations were multiplied by 1.19 and an offset of 1.15 was added. Because of the short $\mathrm{PM}_{2.5}$ time series at Aspvreten (started on 22 June 2006), Norr Malma $\mathrm{PM}_{2.5}$ measurements were used as a replacement of Aspvreten data only for calculations of average values (means of 8.30 and $8.00 \mu \mathrm{g} \mathrm{m}^{-3}$ for the simultaneous measurements) since the linear correlation for the time series was rather low $\left(R_{\text {hourly }}=0.43, R_{\text {daily }}=0.71\right)$ for the period of simultaneous measurements. $\mathrm{NO}_{\mathrm{x}}$ concentrations were measured at the three monitoring sites in central Stockholm and at Norr Malma station using commercial chemiluminescence analyzers (model 31 M LCD, Environment SA, France). Total traffic counts were recorded at Hornsgatan and Essingeleden using automatic counters based on magnetic impedance. Meteorological measurements were conducted at Torkel and Aspvreten including air temperature (Hygroclip probe, Rotronic AG, Switzerland), precipitation (tipping bucket rain gauge, model HB 3166-06, Casella Measurement, UK), and wind speed (WS) and direction (WD) (ultrasonic anemometer, model R3, Gill Instruments Ltd., UK). Sensors were installed at $2 \mathrm{~m}$ above roof at Torkel and $2 \mathrm{~m}$ above ground at Aspvreten, except for the anemometer installed at $10 \mathrm{~m}$ height.

\section{Results and discussion}

\subsection{Comparison of aerosol light-absorption measurements}

Krecl et al. (2007), when comparing Aethalometer and PSAP-ITM measurements in an area impacted by woodsmoke, showed that the custom-built PSAP was a reliable alternative for the commercial Aethalometer. Because of the different physicochemical characteristics of combustion particles from vehicle exhaust and residential woodsmoke (Kocbach et al., 2005), we evaluate here the performance of the custom-built PSAP at a kerbside site (Hornsgatan) and at an urban background monitoring station (Torkel). The PSAP-ITM instruments used in this study were previously intercompared in the laboratory when sampling air from outdoors and showed a very high correlation for 15-min averages ( $R=0.99$ ) (Krecl et al., 2010). Figure 3 displays the linear regression between hourly PSAP-ITM $b_{\text {ap }}$ and Aethalometer $\mathrm{M}_{\mathrm{LAC}}$ for measurements carried out at 

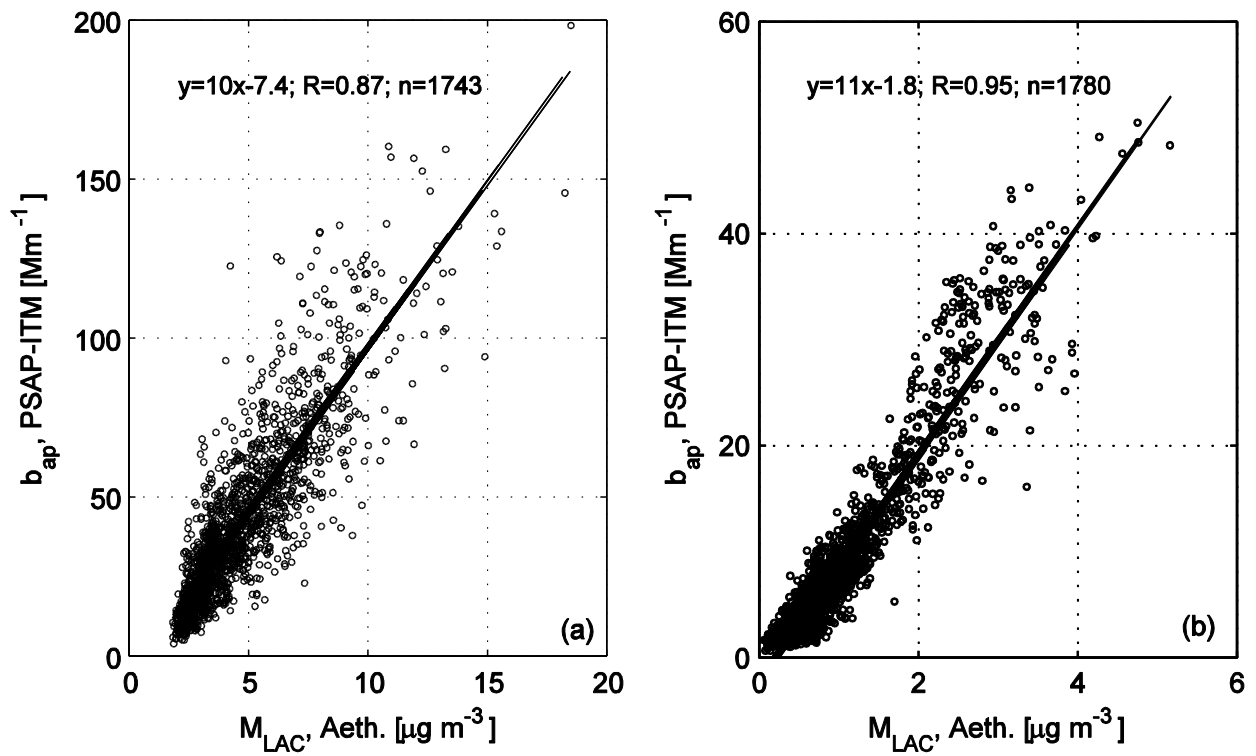

Fig. 3. Linear correlation between hourly mean PSAP-ITM aerosol absorption coefficients and Aethalometer $\mathrm{M}_{\mathrm{LAC}}$ in the period 20 April5 July 2006. (a) Hornsgatan. (b) Torkel. The regression equation, correlation coefficient $R$ and number of samples $\mathrm{n}$ are also displayed.

Hornsgatan (left panel) and at Torkel (right panel) in the period 20 April-5 July 2006. The two methods were found to be highly correlated $(R>0.85)$ for both sites, but a large yintercept $\left(-7.2 \mathrm{Mm}^{-1}\right)$ was observed when correlating the Aethalometer and PSAP-ITM measurements at Hornsgatan, even after subtracting an offset value as described previously. If instead the PSAP-ITM M LAC $_{\text {concentrations are linearly }}$ correlated with the Aethalometer mass concentrations, the slope of the regression line is $1.4 \pm 0.03$ (95\% confidence interval) for both sites (not shown). The slope being larger than 1 might partly result from (a) the use of an Aethalometer $\sigma_{\mathrm{a}}$ value that is not site and season specific for this study (Sharma et al., 2002), and (b) biases of the thermo-optical measurements of EC (Bond and Bergstrom, 2005) used to determine the custom-built PSAP $\sigma_{\mathrm{a}}$. To determine the goodness of the linear fit between hourly PSAP and Aethalometer $M_{\text {LAC }}$ concentrations, the root mean square error RMSE was calculated for both sites. The RMSE values were 1.78 and $0.35 \mu \mathrm{g} \mathrm{m}^{-3}$ for Hornsgatan and Torkel, respectively. The higher RMSE value at Hornsgatan indicates a larger difference between the instrument measurements at this site than at Torkel.

\subsection{General overview}

During the selected sampling period (20 April-5 July 2006), daily mean temperatures ranged between $3.7^{\circ} \mathrm{C}$ and $23.6^{\circ} \mathrm{C}$ at Torkel, and between $3.1^{\circ} \mathrm{C}$ and $19.6^{\circ} \mathrm{C}$ at Aspvreten. The mean wind speed was $3.5 \mathrm{~m} \mathrm{~s}^{-1}$ at Torkel (rooftop) and the prevailing wind directions were south $(22 \%)$, southwest $(18 \%)$, and west $(15 \%)$ whereas Aspvreten mean WS was
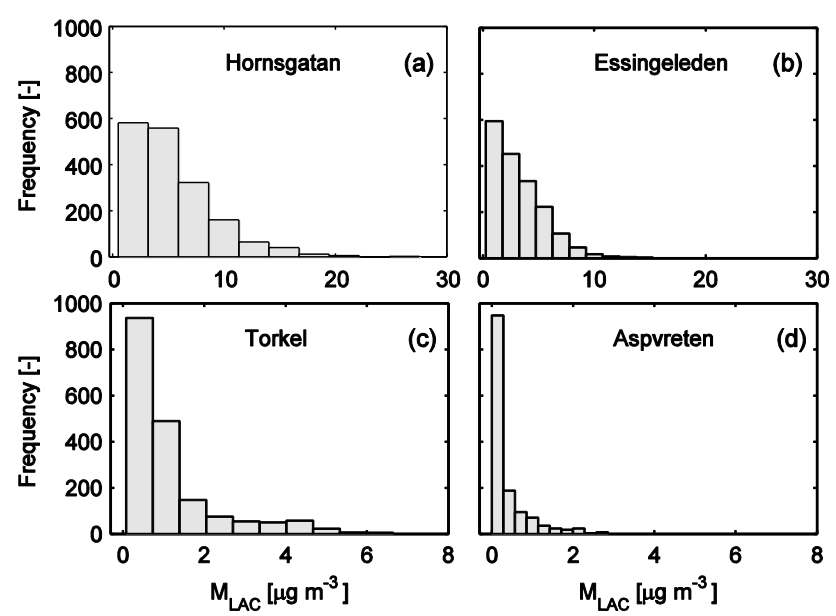

Fig. 4. Frequency-of-occurrence histograms of hourly $\mathrm{M}_{\mathrm{LAC}}$ time series at the four sites in the period 20 April-5 July 2006.

$1.8 \mathrm{~m} \mathrm{~s}^{-1}$ and the dominant winds were from south (22\%), southeast $(20 \%)$, and east $(15 \%)$.

Descriptive statistics and frequency-of-occurrence histograms of hourly mean $\mathrm{M}_{\mathrm{LAC}}$ concentrations measured with the PSAP-ITM for simultaneous measurements in the period 20 April-5 July 2006 are displayed in Table 1 and Fig. 4, respectively. Missing data corresponded to time periods when the instruments were not operating or were known to be operating improperly (e.g., filter transmittance below the recommended threshold, voltage signal higher than the maximum data logger input voltage, maintenance for filter change or flow rate measurement). 
Table 1. Descriptive statistics of hourly $\mathrm{M}_{\mathrm{LAC}}$ concentrations at the four sites for the period 20 April-5 July 2006.

\begin{tabular}{lllll}
\hline $\mathrm{M}_{\mathrm{LAC}}\left[\mu \mathrm{g} \mathrm{m}^{-3}\right]$ & Hornsgatan & Essingeleden & Torkel & Aspvreten \\
\hline Arithmetic mean & 5.39 & 3.23 & 1.13 & 0.36 \\
Median & 4.47 & 2.63 & 0.72 & 0.14 \\
5th percentile & 1.44 & 0.74 & 0.21 & 0.01 \\
95th percentile & 12.46 & 7.51 & 3.99 & 1.58 \\
Arithmetic SD & 3.60 & 2.27 & 1.15 & 0.50 \\
Number of samples & 1744 & 1791 & 1841 & 1412 \\
\hline
\end{tabular}

Table 2. Spatiotemporal variability of $\mathrm{M}_{\mathrm{LAC}}$ time series measured at the four sites in the period 20 April-5 July 2006 . $R$ and COD for hourly and daily (in square brackets) measurements. $R>0.75$ are displayed in bold.

\begin{tabular}{lllll}
\hline Coefficient & Stations & Essingeleden & Torkel & Aspvreten \\
\hline \multirow{3}{*}{$R[-]$} & Hornsgatan & $0.62[0.70]$ & $0.48[0.59]$ & $0.23[0.40]$ \\
& Essingeleden & & $0.50[0.65]$ & $0.27[0.41]$ \\
& Torkel & & & $\mathbf{0 . 7 8}[\mathbf{0 . 8 8}]$ \\
& Hornsgatan & $0.37[0.31]$ & $0.69[0.71]$ & $0.88[0.90]$ \\
COD [-] & Essingeleden & & $0.56[0.56]$ & $0.84[0.86]$ \\
& Torkel & & & $0.66[0.67]$ \\
\hline
\end{tabular}

Mean $\mathrm{M}_{\mathrm{LAC}}$ concentrations ranged from 0.36 to $5.39 \mu \mathrm{g} \mathrm{m}^{-3}$, and standard deviation (SD) varied between 0.50 and $3.60 \mu \mathrm{g} \mathrm{m}^{-3}$. As expected, higher values of $\mathrm{M}_{\mathrm{LAC}}$ concentrations were found at the street canyon site whereas lower levels always corresponded to the rural station. The 95th percentile at Hornsgatan was 12 times higher than the 95th percentile at Aspvreten even for daily averages (not shown), and the lowest values at Hornsgatan (5th percentile) were higher than the average at Aspvreten $\left(1.44 \mu \mathrm{g} \mathrm{m}^{-3}\right.$ versus $\left.0.36 \mu \mathrm{g} \mathrm{m}^{-3}\right)$. The other two urban sites presented intermediate concentrations, with Essingeleden (close to the highway) showing on average 2.8 times higher concentrations than the urban rooftop site. Street level concentrations of $\mathrm{M}_{\mathrm{LAC}}$ in Stockholm (Hornsgatan and Essingeleden) were higher than concentrations measured in a residential area impacted by woodsmoke in Northern Sweden during wintertime (Krecl et al., 2007, 2010). Compared to other European kerbside sampling sites, mean $\mathrm{M}_{\mathrm{LAC}}$ concentrations at Hornsgatan and Essingeleden were within the 3.11-10.68 $\mathrm{g} \mathrm{m} \mathrm{m}^{-3}$ annual average range reported by Putaud et al. (2004). Average values at Aspvreten were similar to other European rural background sites (Putaud et al., 2004), with concentrations lower than $1 \mu \mathrm{g} \mathrm{m}^{-3}$. The Torkel median $\mathrm{M}_{\mathrm{LAC}}$ concentration is comparable to the median value observed at a Tokyo rooftop site $\left(1.18 \mu \mathrm{g} \mathrm{m}^{-3}\right.$, $\sim 20 \mathrm{~m}$ height) in the period 2003-2005 (Kondo et al., 2006). Mean $\mathrm{M}_{\mathrm{LAC}}$ concentrations at two New York city sites were 1.01 and $1.38 \mu^{-3} \mathrm{~m}^{-3}$ for wintertime (Venkatachari et al., 2006), being comparable to Torkel levels but lower than Hornsgatan and Essingeleden mean values. Figure 4 shows the skewed nature of $\mathrm{M}_{\mathrm{LAC}}$ datasets, with positive skewness ranging from 1.28 (Essingeleden) to 2.29 (Aspvreten). These measurements are more closely represented by lognormal distributions (not shown).

A large hour-to-hour and day-to-day variability of $\mathrm{M}_{\mathrm{LAC}}$ concentrations was observed at the kerbside sites whereas concentrations at the rural background station showed very low levels. Figure 5 illustrates the spatiotemporal variability for one example week from 14 May through 20 May 2006 when no long-range transport (LRT) from polluted areas was detected in Stockholm (as observed in HYSPLIT4 backward trajectory analysis and corroborated by the low levels at the rural site Aspvreten). More tellingly, the maximum hourly concentration at Hornsgatan reached $15.84 \mu^{-3} \mathrm{~m}^{-3}$ at 11:00 LT whereas a minimum value of $2.15 \mu \mathrm{g} \mathrm{m}^{-3}$ was observed at 21:00 LT on Friday 19 May. At Aspvreten, $\mathrm{M}_{\mathrm{LAC}}$ concentrations ranged between 0.20 and $0.32 \mu \mathrm{g} \mathrm{m}^{-3}$ for the same day. During that week, the daily mean temperature at Torkel ranged between $7.9^{\circ} \mathrm{C}$ and $10.4{ }^{\circ} \mathrm{C}$ with precipitation records on 17 May $(0.6 \mathrm{~mm}), 18$ May $(3.8 \mathrm{~mm})$, and 20 May $(5.6 \mathrm{~mm})$. The weather at Aspvreten was colder than at Torkel with air temperatures between $5.1^{\circ} \mathrm{C}$ and $9.0^{\circ} \mathrm{C}$ and precipitation records on 17 May $(1.0 \mathrm{~mm}), 18$ May (2.6 $\mathrm{mm})$, and 20 May $(3.2 \mathrm{~mm})$. At both stations, precipitation did not seem to produce significant washout of airborne particles when comparing concentrations in rainy days vs. nonrainy days. This might be explained by the low precipitation rate and amount.

During the present field campaign, a long-range transport of pollutants emitted by agricultural wildfires in Russia and the Baltic region had a strong impact on aerosol concentrations in Sweden in the period 24 April-9 May 2006, mainly 


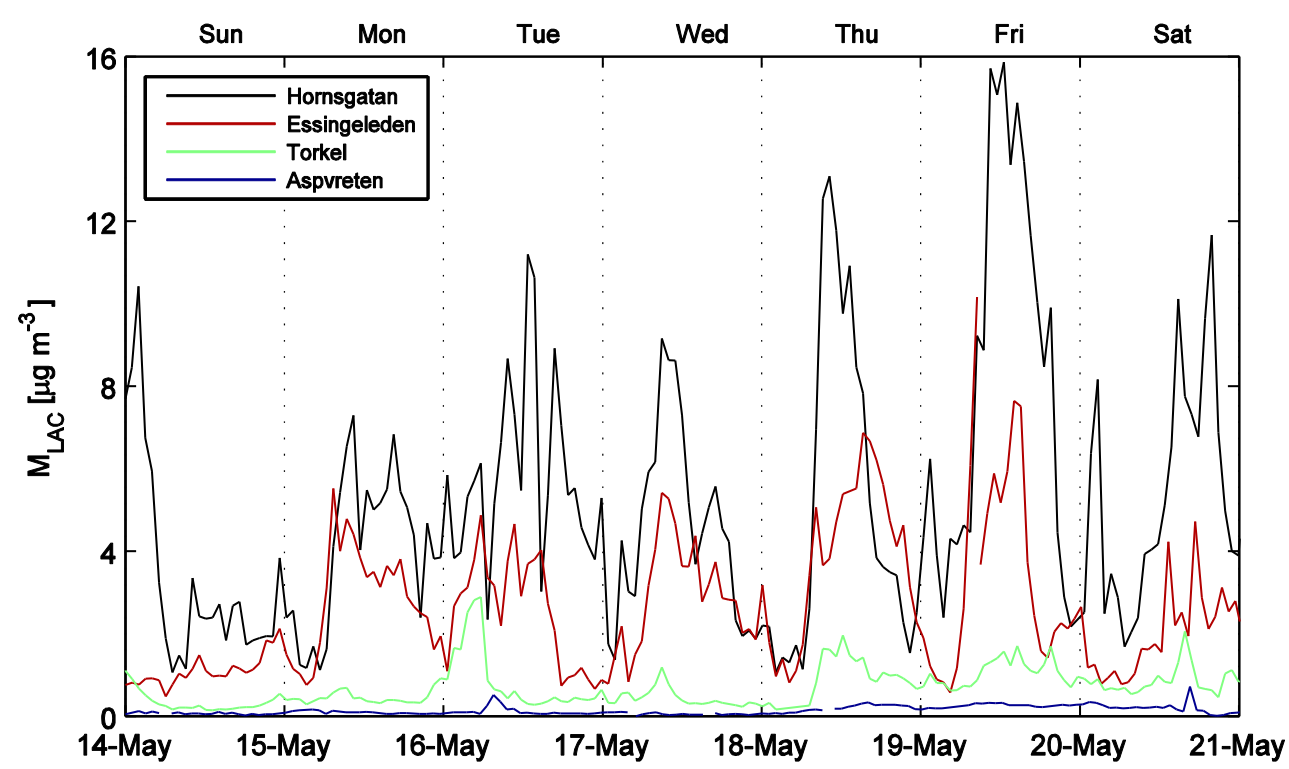

Fig. 5. Time series of hourly mean $M_{\text {LAC }}$ concentrations at the four sites for the period 14-20 May 2006. Date labels are at 00:00 LT. Days of the week are also displayed.

for background sites (Targino et al., 2011). On average, $\mathrm{M}_{\mathrm{LAC}}$ concentrations were 4 times higher at Torkel and 7 times higher at Aspvreten during this LRT episode compared to the rest of the study period.

\subsection{Spatiotemporal variability of $\mathrm{M}_{\mathrm{LAC}}$ concentrations}

Ambient particle concentrations vary spatially and temporally to different degrees at the intraurban scale and two statistical tools are commonly used to determine whether a pollutant concentration is homogeneously distributed in time and space. Correlation coefficients accurately track the temporal similarity of paired measurements conducted at two sites, while coefficients of divergence (COD) are often used to analyze the spatial uniformity of the observations (Wilson et al., 2005).

The Pearson correlation coefficients between $\mathrm{M}_{\mathrm{LAC}}$ time series were calculated for hourly and daily (starting at midnight) mean concentrations during the period of simultaneous measurements and the results are displayed in Table 2 (upper part). All correlation coefficients were significant at the $99 \%$ level (not shown). Daily correlations were higher than hourly correlations for all site pairs. However, daily $\mathrm{M}_{\mathrm{LAC}}$ time series were still poorly correlated except for Aspvreten and Torkel measurements (hourly $R=0.78$; daily $R=0.88$ ). The high correlation between Aspvreten and Torkel could be explained by the long-range transport origin of the $\mathrm{M}_{\mathrm{LAC}}$ observed at the two sites since these sites were not affected by local emission sources.

The coefficients of divergence were calculated according to Wongphatarakul et al. (1998) and results from collocated hourly and daily $\mathrm{M}_{\mathrm{LAC}}$ concentrations in the pe- riod 20 April-5 July 2006 are shown in Table 2 (bottom part). Values lower than 0.20 are indicative of relative spatial uniformity, whereas values approaching one indicate that the concentrations are heterogeneously distributed. At hourly averages, COD values ranged from 0.37 (HornsgatanEssingeleden) to 0.88 (Hornsgatan-Aspvreten), revealing a high spatial heterogeneity in the measured concentrations. The spatial uniformity did not improve when daily averages were considered. This suggest that $\mathrm{M}_{\mathrm{LAC}}$ concentrations are less homogeneous, even at short spatial scales of the order of a few kilometers, than usually assumed in health and exposure studies. Thus, analysis of health effects on the population due to short term (hours-days) $\mathrm{M}_{\mathrm{LAC}}$ exposure based on single point measurements would likely tend to underestimate the significance of the exposure-response coefficients due to misclassified exposure in an urban area like Stockholm.

\subsection{Linear correlation between pollutants concentrations}

Table 3 displays the average concentrations of $\mathrm{NO}_{\mathrm{x}}, \mathrm{PM}_{10}$, and $\mathrm{PM}_{2.5}$ measurements conducted simultaneously at all sites. Note that $\mathrm{NO}_{\mathrm{x}}$ was not measured at Aspvreten. It can be seen that $\mathrm{NO}_{\mathrm{x}}$ concentrations decreased sharply $(\sim 20$ times) when moving from the street canyon site (Hornsgatan) to the rural station (Norr Malma) showing the dominant role of local anthropogenic emissions on $\mathrm{NO}_{\mathrm{x}}$ levels. A similar reduction ( $\sim 24$ times) was found when comparing $\mathrm{NO}_{\mathrm{x}}$ concentrations at kerbside and rural sites in the Copenhagen area and Southern Sweden in fall 2002 (Ketzel et al., 2004). In this study, $\mathrm{PM}_{10}$ concentrations also decreased from the 
Table 3. Arithmetic mean $\mathrm{NO}_{\mathrm{x}}, \mathrm{PM}_{10}, \mathrm{PM}_{2.5}$ concentrations at the different sites for the period 20 April-5 July 2006.

\begin{tabular}{llllll}
\hline Concentration $\left[\mu \mathrm{g} \mathrm{m}^{-3}\right]$ & Hornsgatan & Essingeleden & Torkel & Aspvreten & Norr Malma \\
\hline $\mathrm{NO}_{\mathrm{X}}$ & 109.6 & 74.4 & 15.9 & - & 5.3 \\
$\mathrm{PM}_{10}$ & 46.1 & 47.4 & 22.0 & 15.2 & 15.0 \\
$\mathrm{PM}_{2.5}$ & $12.8^{a}$ & 12.2 & 10.8 & $8.5^{\mathrm{a}}$ & 10.4 \\
\hline
\end{tabular}

a Reduced data availability in the selected period: $36 \%$ at Hornsgatan, and $10 \%$ at Aspvreten.

kerbside stations to the rural sites and mean $\mathrm{PM}_{2.5}$ levels were similar at all sites within one standard deviation (not shown). Ketzel et al. (2004) also reported lower PM $_{10}$ levels at background sites $\left(9.0-10.3 \mu \mathrm{g} \mathrm{m}^{-3}\right)$ than at kerbside stations $\left(17.2-29.5 \mu \mathrm{g} \mathrm{m}^{-3}\right)$.

Average concentrations ratios at each site were calculated as the ratio between mean concentrations of each pollutant. Due to missing $\mathrm{PM}_{2.5}$ data at Hornsgatan and Aspvreten during the study period, the following procedure was applied: (a) calculations of $\mathrm{M}_{\mathrm{LAC}} / \mathrm{PM}_{2.5}$ and $\mathrm{PM}_{2.5} / \mathrm{PM}_{10}$ ratios at Hornsgatan were restricted to periods of simultaneous valid data, (b) the rural mean $\mathrm{PM}_{2.5}$ value used in the calculations corresponded to Norr Malma. The mean $\mathrm{NO}_{\mathrm{x}} / \mathrm{M}_{\mathrm{LAC}}$ ratios ranged between 20.3 and 23.0 at the kerbside locations, which is consistent with ratios observed close to major roads (distance of 5-10 m) in Japanese urban areas (Naser et al., 2009). The mean $\mathrm{M}_{\mathrm{LAC}} / \mathrm{PM}_{2.5}$ ratio is larger at the kerbside stations (38\% at Hornsgatan, and $26 \%$ at Essingeleden) than at the background sites (10\% at Torkel, and $4 \%$ at Aspvreten) as observed by Putaud et al. (2004) when studying the chemical characteristics of the particulate matter across Europe. The strongly decreasing $\mathrm{PM}_{2.5} / \mathrm{PM}_{10}$ ratio from rural (0.69) to kerbside sites (0.26), indicates a higher emission of coarse particles in the urban area (e.g. road dust emissions, Norman and Johansson, 2006).

Linear correlations between hourly concentrations of atmospheric pollutants $\left(\mathrm{M}_{\mathrm{LAC}}, \mathrm{PM}_{10}, \mathrm{PM}_{2.5}\right.$, and $\left.\mathrm{NO}_{\mathrm{x}}\right)$ measured at each station were calculated in the period 20 April5 July 2006: (1) excluding data during the LRT event (24 April-9 May 2006), (2) including all days. Table 4 displays the inner city correlation coefficients only when local sources dominated the pollutants emissions (period 1). The number of valid samples ranged from 171 to 1451 because not all instruments were always operating correctly, and this variation has to be considered when comparing $R$ values. High $R$ values $(R>0.75)$ were only observed for the variable combination $\mathrm{M}_{\mathrm{LAC}}-\mathrm{NO}_{\mathrm{x}}$ at all urban stations, suggesting that both compounds originated mainly from vehicle traffic emissions. For period 2, the correlation between $\mathrm{M}_{\mathrm{LAC}}$ and $\mathrm{NO}_{\mathrm{x}}$ concentrations decreased to 0.47 at Torkel (not shown) and remained constant for the kerbside sites. This finding indicates a strong contribution of the LRT episode to $\mathrm{M}_{\mathrm{LAC}}$ concentrations at Torkel whereas $\mathrm{NO}_{\mathrm{x}}$ was emitted by local pollution sources. The correlation between $\mathrm{M}_{\mathrm{LAC}}$ and $\mathrm{PM}_{10}$
Table 4. Linear correlation coefficients between hourly concentrations of different species measured at each site in the period 20 April-5 July 2006, but excluding the aerosol LRT event on 24 April-9 May 2006. $\mathrm{n}$ indicates the number of paired data for each combination. $R>0.75$ are displayed in bold.

\begin{tabular}{lllllll}
\hline$R[-]$ & $\mathrm{M}_{\mathrm{LAC}}$ & $\mathrm{M}_{\text {LAC }}$ & $\mathrm{M}_{\text {LAC }}$ & $\mathrm{NO}_{\mathrm{x}}$ & $\mathrm{NO}_{\mathrm{x}}$ & $\mathrm{PM}_{2.5}$ \\
& $\mathrm{NO}_{\mathrm{x}}$ & $\mathrm{PM}_{10}$ & $\mathrm{PM}_{2.5}$ & $\mathrm{PM}_{2.5}$ & $\mathrm{PM}_{10}$ & $\mathrm{PM}_{10}$ \\
\hline Hornsgatan & $\mathbf{0 . 7 8}$ & 0.44 & 0.64 & 0.50 & 0.51 & 0.67 \\
$n$ & 1368 & 1382 & 625 & 664 & 1438 & 673 \\
Essingeleden & $\mathbf{0 . 9 0}$ & 0.45 & 0.57 & 0.42 & 0.48 & 0.38 \\
$n$ & 1443 & 1412 & 1330 & 1350 & 1433 & 1348 \\
Torkel & $\mathbf{0 . 7 6}$ & 0.36 & 0.55 & 0.20 & 0.17 & 0.52 \\
$n$ & 1389 & 1451 & 1305 & 1240 & 1386 & 1306 \\
Aspvreten & - & 0.45 & 0.35 & - & - & 0.73 \\
$n$ & & 1037 & 171 & & & 176 \\
\hline
\end{tabular}

time series at the background sites increased ( 0.75 at Torkel and 0.85 at Aspvreten, not shown) when including the LRT episode, suggesting a common aerosol origin. An important correlation increase $(R=0.89)$ was observed at Torkel when analyzing $\mathrm{M}_{\mathrm{LAC}}$ and $\mathrm{PM}_{2.5}$ measurements, in contrast to the weak correlation $(R=0.41)$ at Aspvreten (probably caused by the relative small number of valid measurements).

\subsection{Diurnal patterns}

The diurnal variation of mean $\mathrm{M}_{\mathrm{LAC}}, \mathrm{PM}_{10}, \mathrm{PM}_{2.5}$, and $\mathrm{NO}_{\mathrm{x}}$ concentrations for the 4 sites is shown in Fig. 6, together with the daily pattern of traffic density at Hornsgatan and Essingeleden. Measurements were classified as weekdays (Monday-Friday) and weekends (Saturday-Sunday) and mean hourly values were calculated for the period 20 April-5 July 2006. $\mathrm{PM}_{2.5}$ data from Norr Malma replaced Aspvreten measurements for this calculation due to the low data availability (only $10 \%$ ). Because of missing $\mathrm{PM}_{2.5} \mathrm{ob}-$ servations at Hornsgatan ( $36 \%$ data coverage), $\mathrm{PM}_{2.5}$ weekend daily patterns at these sites were not fully synchronized with the other observations. Time displayed in Fig. 6 corresponds to local time (LT).

It can be observed that pollutant concentrations were generally higher on weekdays than at weekends between early morning and evening at the urban sites. To test the significance of the weekday concentrations being higher than the 

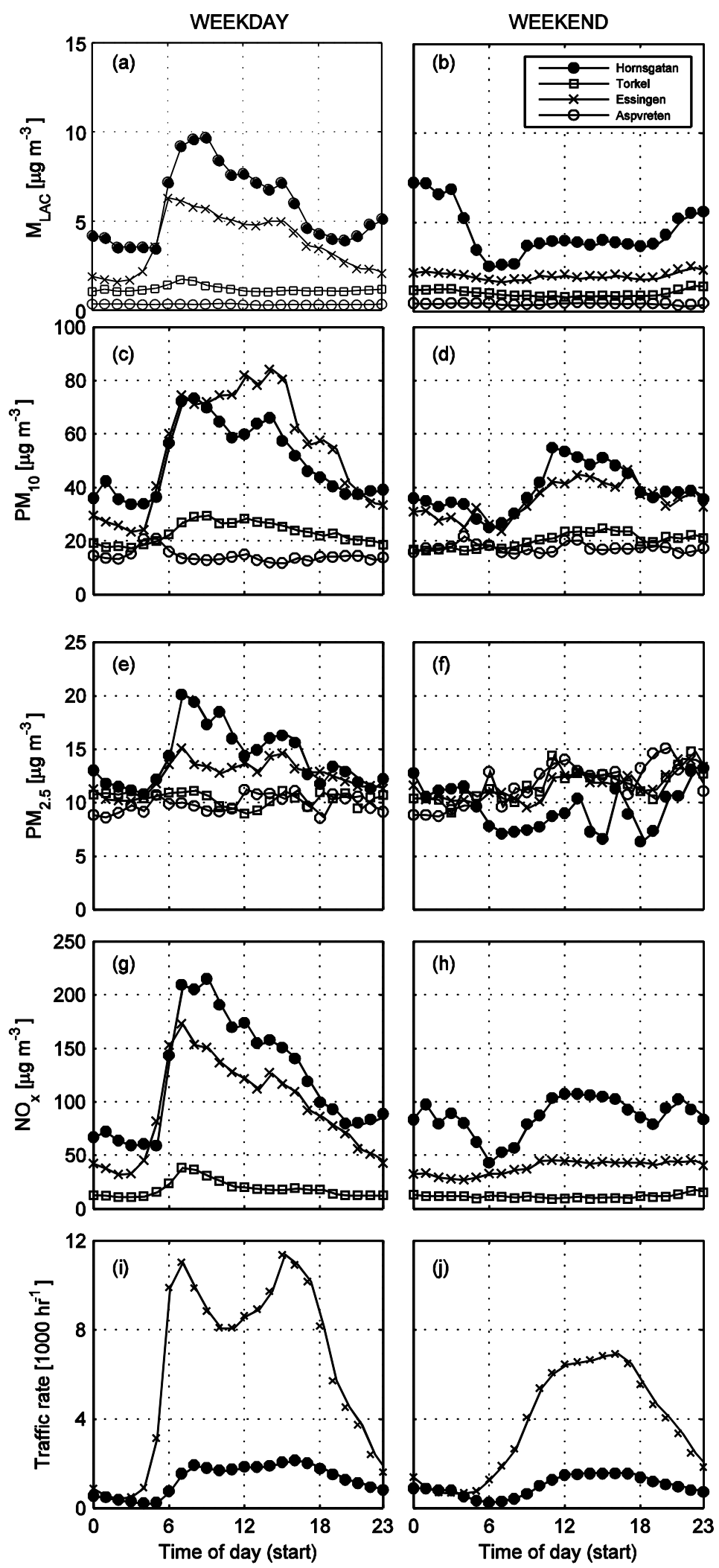

Fig. 6. Average diurnal variation of $\mathrm{M}_{\mathrm{LAC}}, \mathrm{PM}_{10}, \mathrm{PM}_{2.5}, \mathrm{NO}_{\mathrm{x}}$, and traffic rate on weekdays and weekends for the four stations in the period 20 April-5 July 2006. Aspvreten $\mathrm{PM}_{2.5}$ concentrations were replaced by Norr Malma data. 
weekend levels, a non-parametric Mann-Whitney U test was performed on the median difference concentration for each hour of the day at $95 \%$ confidence level. Measurements at Aspvreten showed no significant difference between weekend and weekdays for all variables analyzed, indicating no evidence of local anthropogenic activities. Weekday concentrations were statistically significantly higher than weekend levels for: (1) $\mathrm{M}_{\mathrm{LAC}}$ concentrations at all urban stations during daytime (07:00-20:00), (2) $\mathrm{PM}_{10}$ concentrations in the morning and early afternoon (08:00-15:00) at Hornsgatan and Torkel, and during daytime (07:00-20:00) at Essingeleden, (3) $\mathrm{NO}_{\mathrm{x}}$ levels at the three urban sites during daytime (06:00-20:00), (4) $\mathrm{PM}_{2.5}$ concentrations only at Hornsgatan in the period 07:00-20:00 (this result should be considered with caution as previously mentioned).

On weekdays, the pollutants concentration rise observed at the kerbside stations in the early morning (05:00-06:00) was consistent with an increase in vehicle traffic, and maximum values were reached at $\sim 09: 00$. Peak values were followed by a gradual decrease in $\mathrm{M}_{\mathrm{LAC}}$ and $\mathrm{NO}_{\mathrm{x}}$ concentrations at both sites through the afternoon, partially explained by the well-documented growth of the mixing layer depth and strong turbulent mixing during the afternoon. A similar pattern for $\mathrm{NO}_{\mathrm{x}}$ was observed at Hornsgatan by Olivares et al. (2007) when analyzing diurnal variations on weekdays and at weekends in the period June 2002-September 2004. Hornsgatan $\mathrm{M}_{\mathrm{LAC}}$ diurnal cycle was similar to the pattern observed at Vallila kerbside station in Helsinki during three campaigns conducted between 1996 and 2005 (Järvi et al., 2008). However, Hornsgatan median concentrations were much higher than Valilla levels (4.47 versus $1.11 \mu \mathrm{g} \mathrm{m}^{-3}$ ) as well as morning peak values on weekdays (9.69 versus $2.40 \mu \mathrm{g} \mathrm{m}^{-3}$ ).

Weekday and weekend daily patterns of traffic rate were distinct for Hornsgatan and Essingeleden as depicted in Fig. 6i-j. On average, the traffic volume at Essingeleden was 4.5 times higher than at Hornsgatan. On weekdays, two peaks represented the morning (06:00-09:00) and afternoon (14:00-18:00) traffic rush hours at both sites with moderate traffic volume between these periods. In the early morning (00:00-05:00) at weekends, the traffic rate was higher at weekends than on weekdays, particularly at Hornsgatan station.

Even though the vehicle traffic was more intensive at Essingeleden than at Hornsgatan, pollutants concentrations were usually higher at Hornsgatan. This is most likely mainly connected to poor ventilation conditions at Hornsgatan because of the street canyon geometry. Higher $\mathrm{PM}_{10}$ concentrations were observed at Essingeleden than at Hornsgatan during the afternoon on weekdays, which might be explained by higher road dust emissions due to the higher vehicle speed at Essingeleden than at Hornsgatan. At weekends, a reduced number of vehicles circulated and the contribution of road resuspended particles to the $\mathrm{PM}_{10}$ fraction was smaller than on weekdays. Thus, Hornsgatan $\mathrm{PM}_{10}$ concentrations were slightly higher than at Essingeleden on Saturday-Sunday.

During early morning hours (00:00-05:00), Hornsgatan $\mathrm{M}_{\mathrm{LAC}}$ and $\mathrm{NO}_{\mathrm{x}}$ concentrations were found statistically significantly higher at weekends than on weekdays (MannWhitney U test, $95 \%$ confidence level). This rise beyond the evening rush hour at Hornsgatan might be due to the higher early morning traffic at weekends than on weekends, mainly composed of diesel taxis (Burman and Johansson, 2010) and possibly associated to leisure-time activities in Stockholm downtown area.

\subsection{Wind dependence}

Wind direction is a key variable to determine the relative position of the measuring sites to the main pollutants emission sources. To study the pollutants concentration dependence on the wind direction, the concentration roses of the pollutants time series were calculated for each site. Figure 7 displays the $\mathrm{M}_{\mathrm{LAC}}, \mathrm{PM}_{10}$, and $\mathrm{NO}_{\mathrm{x}}$ concentration roses at the four sites for the whole period of simultaneous measurements (Fig. 7a-c), and excluding measurements during the LRT event (Fig. 7d-f). Due to the poor data coverage of $\mathrm{PM}_{2.5}$ measurements at Hornsgatan and Aspvreten, $\mathrm{PM}_{2.5}$ concentration roses were calculated only for Essingeleden and Torkel (not shown). The average of hourly concentrations was calculated for each WD sector $\left(22.5^{\circ}\right)$ including only data records with valid measurements from all sites.

Pollutants concentrations at the kerbside stations are higher than backgrounds levels for all wind directions. $M_{L A C}$ and $\mathrm{NO}_{\mathrm{x}}$ concentrations roses showed the same pattern for the kerbside stations during both periods (i.e. including and excluding the LRT event). This suggests that local emission sources (i.e. traffic exhaust) were the main contributors to $\mathrm{M}_{\mathrm{LAC}}$ and $\mathrm{NO}_{\mathrm{x}}$ measurements at Hornsgatan and Essingeleden. However, Torkel and Aspvreten concentration roses for $\mathrm{M}_{\mathrm{LAC}}$ showed a distinct behavior. When the LRT episode was included, $\mathrm{M}_{\mathrm{LAC}}$ concentrations were higher at both sites for $\mathrm{E}$ and SE winds (Fig. 7a), matching the predominant WD at Torkel and Aspvreten during the agricultural wildfires episode in Russia. The reader is referred to Targino et al. (2011) for details on the impact of this wildfires episode on the Swedish air quality, including air mass back trajectory analysis. $M_{\mathrm{LAC}}$ levels were lower at the background sites when the LRT episode was excluded and the WD dependence was negligible (Fig. 7d). PM $_{10}$ concentrations showed a positive WD dependence at all sites for SE and $\mathrm{E}$ winds when the LRT event was present in the analysis (Fig. 7b). Hornsgatan concentration roses for $\mathrm{M}_{\mathrm{LAC}}$ and $\mathrm{NO}_{\mathrm{x}}$ presented the highest values associated with the NE and E sectors matching the street canyon orientation of $75^{\circ}$ from the north towards the east. Gidhagen et al. (2004b) showed that modeled $\mathrm{NO}_{\mathrm{x}}$ levels at the Hornsgatan site were improved when traffic emissions from the surrounding streets, especially in the sector $40^{\circ}-140^{\circ}$, were included in the simulations. This 

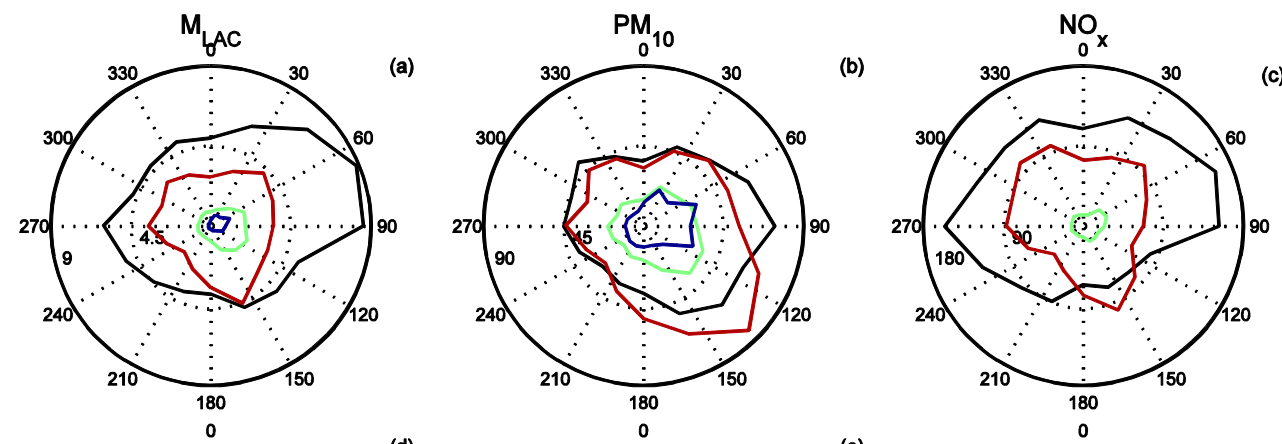

(c)
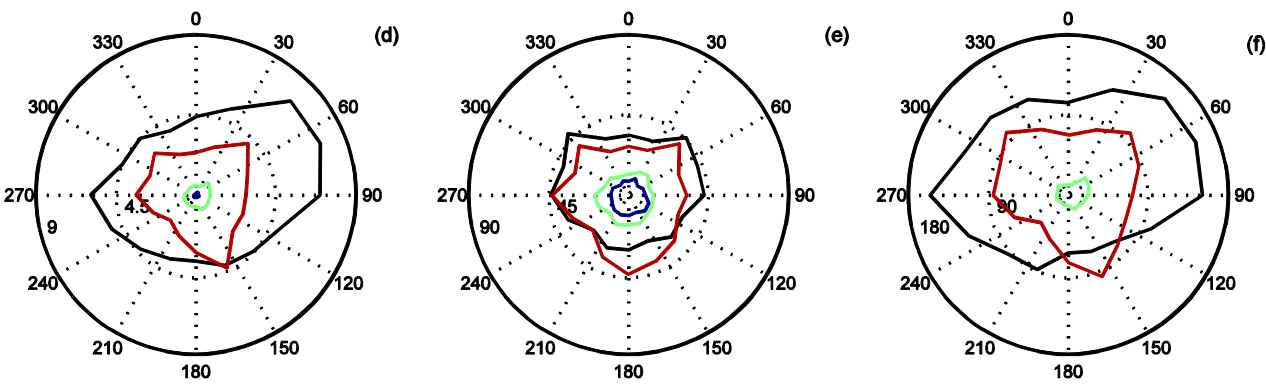

Fig. 7. Rose plots of pollutant concentrations $\left(\mathrm{M}_{\mathrm{LAC}}, \mathrm{PM}_{10}\right.$, and $\left.\mathrm{NO}_{\mathrm{x}}\right)$ based on hourly measurements at the four sites and expressed as $\mu \mathrm{g} \mathrm{m}^{-3}$. Top panel (a-c): whole period 20 April-5 July 2006. Bottom panel (d-f): measurements in the period 24'April-9 May 2006 were excluded (LRT event). Color code: Hornsgatan (black), Essingeleden (red), Torkel (green), and Aspvreten (blue).

suggests that $\mathrm{M}_{\mathrm{LAC}}$ and $\mathrm{NO}_{\mathrm{x}}$ emitted by traffic in the neighborhood (NE-E of Hornsgatan site) might have been transported along the street canyon contributing to the high load observed at Hornsgatan.

Hourly concentrations were classified according to the corresponding WS in intervals of $1 \mathrm{~m} \mathrm{~s}^{-1}$ to investigate the WS dependence of the pollutant concentrations at the urban sites excluding the LRT episode. Then the median and interquartile range were computed for each species and WS interval. Concentrations of $\mathrm{PM}_{10}, \mathrm{M}_{\mathrm{LAC}}$, coarse particles $\left(\mathrm{PM}_{10}-\mathrm{PM}_{2.5}\right)$ and $\mathrm{NO}_{\mathrm{x}}$ versus WS are displayed in Fig. 8. Due to the low data coverage of $\mathrm{PM}_{2.5}$ concentrations at Hornsgatan, the WS dependence of the coarse fraction was not included for this site. $\mathrm{M}_{\mathrm{LAC}}$ was diluted in a similar way as $\mathrm{NO}_{\mathrm{x}}$ (mainly emitted by vehicle exhausts) whereas a positive wind speed dependence of $\mathrm{PM}_{10}$ and coarse particles was found for WS $>6 \mathrm{~m} \mathrm{~s}^{-1}$. The increase in $\mathrm{PM}_{10}$ concentrations for the highest WS was due to the increase of the coarse particle fraction with WS. In Stockholm, dust resuspension is mostly produced by road abrasion when vehicles still use studded tires and paved roads are dry (Norman and Johansson, 2006).

These results indicate that $\mathrm{M}_{\mathrm{LAC}}$ was mainly emitted by vehicle traffic at the kerbside stations whereas the LRT contribution to the LAC concentrations was masked at these sites. $\mathrm{NO}_{\mathrm{x}}$ was mostly emitted by traffic sources in the urban area and no agricultural wildfires influence was observed on $\mathrm{NO}_{\mathrm{x}}$ levels at the three sites. Both $\mathrm{PM}_{10}$ and $\mathrm{PM}_{2.5}$ concentrations were strongly impacted by the LRT event at all sites. In urban areas, concentrations of $\mathrm{PM}_{10}$ and coarse particles showed a positive WS dependency due to local dust generation by road abrasion.

\subsection{Urban versus rural contributions}

Figure 9 displays the scattergram of $\mathrm{NO}_{\mathrm{x}}$ versus $\mathrm{M}_{\mathrm{LAC}}$ concentrations at Hornsgatan, Essingeleden, and Torkel. Only measurements conducted on weekdays and outside the LRT event period were averaged separately for each hour of the day and then linearly correlated. For the kerbside stations, the weekday diurnal variations of $\mathrm{M}_{\mathrm{LAC}}$ and $\mathrm{NO}_{\mathrm{x}}$ showed a high linear correlation $(R>0.95)$, indicating that these compounds had common emission sources. Hornsgatan and Essingeleden sites presented similar slopes of 24.9 and 27.3, respectively. At Torkel, the linear correlation between $\mathrm{M}_{\mathrm{LAC}}$ and $\mathrm{NO}_{\mathrm{x}}$ diurnal variation was lower $(R=0.87)$ than at the kerbside sites. The correlation at Torkel increased to $R=$ 0.99 when measurements were restricted to the time period 08:00-18:00 LT and the slope was 28.5 \pm 8.6 (not shown). The $\mathrm{x}$-intercept of the regression lines in Fig. 9 represents an estimate of a "clean" regional background of $\mathrm{M}_{\mathrm{LAC}}$ that is not influenced by local emissions (assuming that $\mathrm{NO}_{\mathrm{x}}$ concentrations are zero in this "clean" background). The $\mathrm{x}$ intercepts ranged from 0.1 to $0.4 \mu \mathrm{g} \mathrm{m}^{-3}$, which is consistent with mean $\mathrm{M}_{\mathrm{LAC}}$ concentrations at the rural site Aspvreten. Thus, a large influence of traffic emissions on $\mathrm{M}_{\mathrm{LAC}}$ and $\mathrm{NO}_{\mathrm{x}}$ concentrations was observed on weekdays at Hornsgatan and Essingeleden, and at Torkel but restricted to the period 08:00-18:00 LT when the traffic volume is higher at Hornsgatan. 

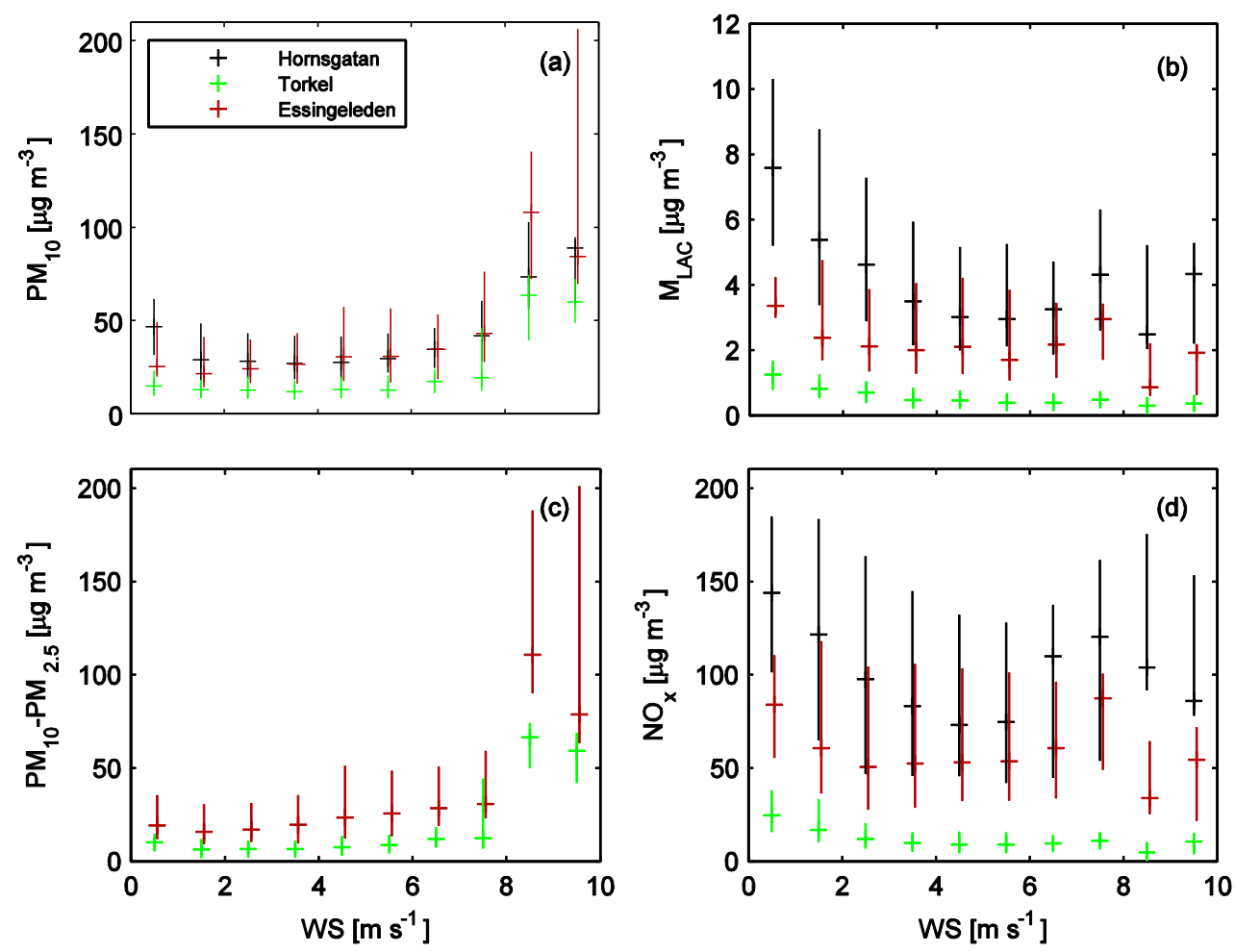

Fig. 8. Weed speed dependence of $\mathrm{PM}_{10}$ (a), $\mathrm{M}_{\mathrm{LAC}}(\mathbf{b}), \mathrm{PM}_{10}-\mathrm{PM}_{2.5}$ (c), and $\mathrm{NO}_{\mathrm{x}}$ (d) for the urban stations in the period 20 April-5 July 2006 (excluding the LRT event). Median and interquartile range concentrations are plotted.

Finally, we illustrate the contribution of the urban sources relative to the regional background levels and discuss the potential to decrease urban concentrations by reducing local emission of atmospheric pollutants following Ketzel et al. (2004). Figure 10 displays the mean weekday concentrations at the different locations relative to the concentrations at the urban background site (Torkel, equal to $100 \%$ ). Rural $\mathrm{NO}_{\mathrm{x}}$ and $\mathrm{PM}_{2.5}$ data correspond to Norr Malma station. The concentrations bars are stacked so that only additional contributions are displayed. A much larger difference between rural and urban levels is observed for $\mathrm{M}_{\mathrm{LAC}}$ and $\mathrm{NO}_{\mathrm{x}}$ compared to $\mathrm{PM}_{10}$ and $\mathrm{PM}_{2.5}$ concentrations. For $\mathrm{M}_{\mathrm{LAC}}$ and $\mathrm{NO}_{\mathrm{x}} 70-75 \%$ of the concentrations were generated in the urban area whereas only $35 \%$ of $\mathrm{PM}_{10}$ and $5 \%$ of $\mathrm{PM}_{2.5}$ corresponded to local urban sources. Regarding the kerbside stations, $\mathrm{M}_{\mathrm{LAC}}$ and $\mathrm{NO}_{\mathrm{x}}$ levels were $310-660 \%$ relatively higher than urban background levels whereas $\mathrm{PM}_{10}$ and $\mathrm{PM}_{2.5}$ concentrations were $130-230 \%$ higher relative to Torkel. Hence, the potential for reducing pollutants urban concentrations in Stockholm by controlling local emissions is much higher for $\mathrm{M}_{\mathrm{LAC}}$ and $\mathrm{NO}_{\mathrm{x}}$ compared to $\mathrm{PM}_{2.5}$ and $\mathrm{PM}_{10}$.

\section{Summary and conclusions}

Atmospheric LAC concentrations were simultaneously sampled using custom-built PSAPs in spring 2006 in Stockholm at four locations, representing urban, urban background and rural pollution levels. These custom-built photometers were found to be a reliable alternative for the commercial Aethalometer, as indicated by the high linear correlation $(R>0.85)$ observed when comparing hourly time series.

As expected, higher $\mathrm{M}_{\mathrm{LAC}}$ concentrations were registered at the urban sites than at the background locations. A large hour-to-hour and day-to-day variability of $\mathrm{M}_{\mathrm{LAC}}$ concentrations was observed at the kerbside locations and the variability was clearly negligible at the rural site, but for an intrusion of a polluted air mass transporting agricultural wildfire combustion products emitted in Russia and the Baltic region. Concentrations of LAC between urban sites were poorly correlated even for daily averages $(R<0.70)$, combined with highly heterogeneously distributed concentrations $(C O D>0.30)$ even at short spatial scales of the order of few kilometers.

Other commonly monitored atmospheric pollutants (namely $\mathrm{PM}_{10}, \mathrm{PM}_{2.5}$, and $\mathrm{NO}_{\mathrm{x}}$ ) were analyzed to help characterize LAC emission sources. In this study, two sources of LAC were identified in the Stockholm area: vehicle exhaust emissions and long-range transport of 


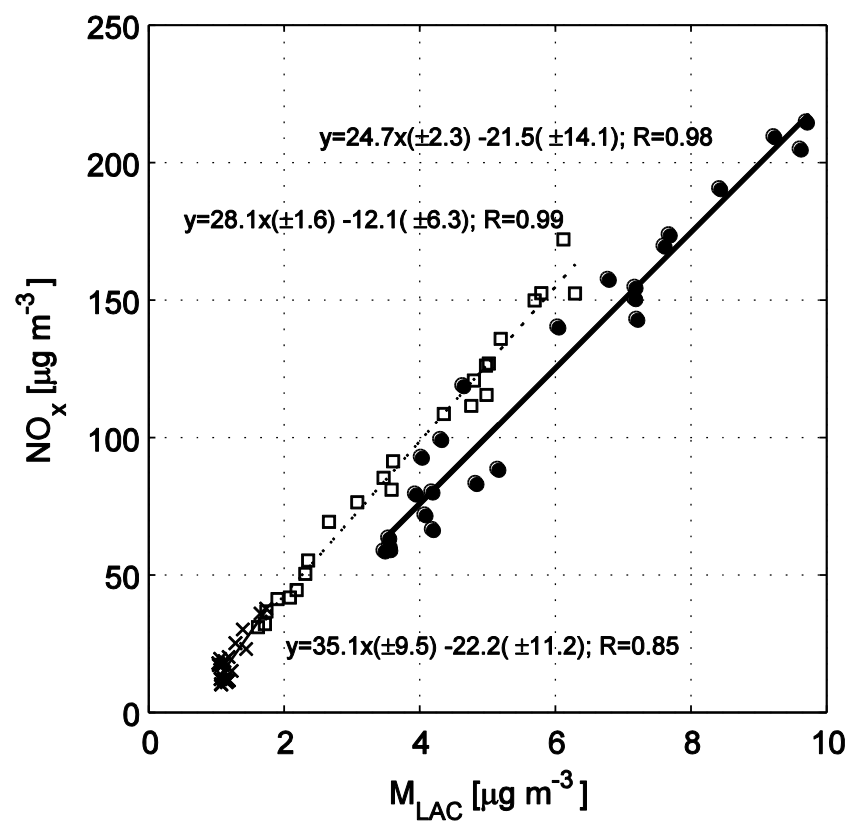

Fig. 9. Scatterplot of $\mathrm{M}_{\mathrm{LAC}}$ versus $\mathrm{NO}_{\mathrm{x}}$ weekday diurnal variation concentrations for three sites (black dot: Hornsgatan, square: Essingeleden, cross: Torkel) in the period 20 April-5 July 2006, excluding the LRT event. The regression equation with the $95 \%$ confidence intervals for the slope and y-intercept, and correlation coefficient $R$ are also displayed.

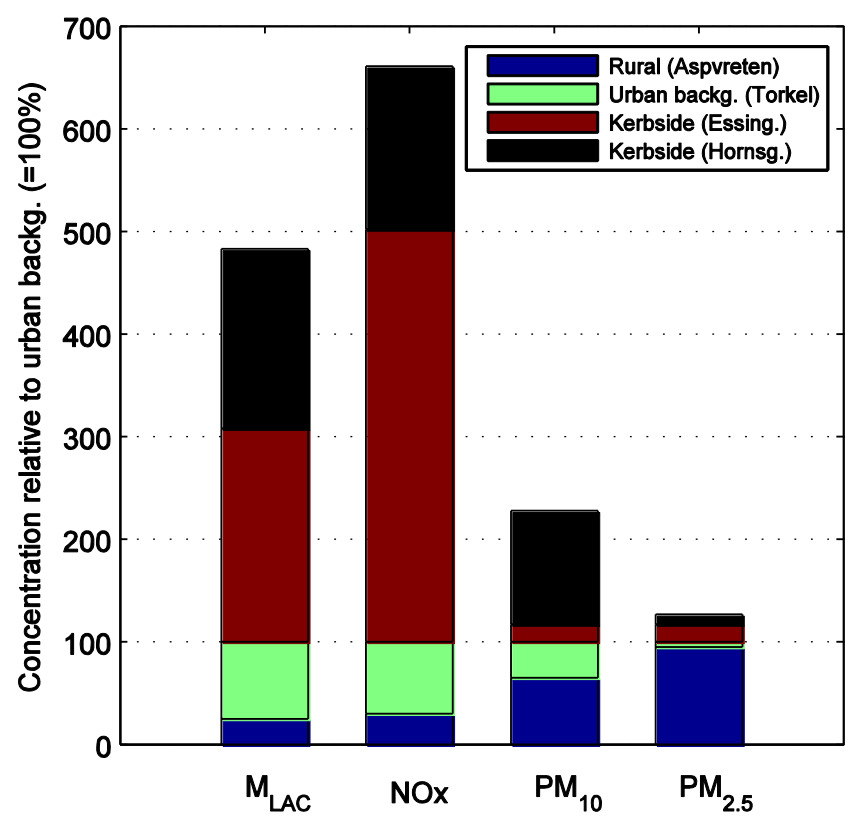

Fig. 10. Comparison of weekday $\mathrm{M}_{\mathrm{LAC}}, \mathrm{NO}_{\mathrm{x}}, \mathrm{PM}_{10}$ and $\mathrm{PM}_{2.5}$ concentrations at a rural, urban background, and kerbside stations relative to urban background concentrations. Rural $\mathrm{NO}_{\mathrm{x}}$ and $\mathrm{PM}_{2.5}$ data correspond to Norr Malma station. combustion-derived particles. This can be explained by inspection of five main indicators: (1) The high correlation $(R>0.75)$ between hourly $\mathrm{M}_{\mathrm{LAC}}$ and $\mathrm{NO}_{\mathrm{x}}$ simultaneous measurements at the urban sites, when no LRT episodes were observed. $\mathrm{NO}_{\mathrm{x}}$ is a tracer for vehicle emissions and a high correlation between $\mathrm{M}_{\mathrm{LAC}}$ and $\mathrm{NO}_{\mathrm{x}}$ suggested a common origin; (2) The statistically significantly higher $\mathrm{M}_{\mathrm{LAC}}$ and $\mathrm{NO}_{\mathrm{x}}$ concentrations at weekends than on weekends in the early morning at Hornsgatan matching with higher traffic density of diesel vehicles; (3) The even higher correlation $(R>0.95)$ between weekday average diurnal concentrations of $\mathrm{M}_{\mathrm{LAC}}$ and $\mathrm{NO}_{\mathrm{x}}$ at the kerbside stations consistent with traffic density daily cycles at both locations; (4) The same pattern of $\mathrm{M}_{\mathrm{LAC}}$ and $\mathrm{NO}_{\mathrm{x}}$ concentration roses at the kerbside stations even when the LRT episode was considered in the data analysis. When the LRT event was included in the background station calculations, $\mathrm{M}_{\mathrm{LAC}}$ concentrations are highest for $\mathrm{E}$ and $\mathrm{SE}$ sectors, matching the predominant wind direction during the agricultural wildfires episode. This suggests that local emission sources (i.e. traffic exhaust) were the main contributors to $\mathrm{M}_{\mathrm{LAC}}$ and $\mathrm{NO}_{\mathrm{x}}$ measurements at kerbside locations and the LRT contribution to the LAC fraction was masked at these sites; and (5) The average $\mathrm{NO}_{\mathrm{X}} / \mathrm{M}_{\mathrm{LAC}}$ ratios in the range 20-23, characteristic of areas impacted by high traffic exhaust emissions.

To what extent the limit values for $\mathrm{PM}_{2.5}$ and $\mathrm{PM}_{10}$ regulate the LAC concentrations depends on the relative contribution of different emission sources to a specific particulate matter fraction, since LAC is a fraction of these two. We observed a larger $\mathrm{M}_{\mathrm{LAC}} / \mathrm{PM}_{2.5}$ ratio at the kerbside stations than at the background sites and correlations were only strong for the rooftop site when the LRT event was considered. Thus, the use of $\mathrm{PM}_{2.5}$ as a proxy to estimate emission trends and projections of LAC concentrations should be used with caution.

This study highlights the benefit of highly resolved spatiotemporal measurements to accurately characterize the complexity of the particulate field across an urban area, and especially the carbon content fraction, to improve the intraurban assessment of human exposure to air pollution.

The potential for decreasing pollutants urban concentrations in Stockholm by reducing local emissions was analyzed by comparing the urban and urban background contributions to the air pollution levels. Abatement strategies should target reductions of vehicle exhaust emissions, after the much higher potential for $\mathrm{M}_{\mathrm{LAC}}$ and $\mathrm{NO}_{\mathrm{x}}$ to reduce pollution levels in urban areas (kerbside and urban background locations) compared to the potential of $\mathrm{PM}_{2.5}$ and $\mathrm{PM}_{10}$.

To what extent the limit values for $\mathrm{PM}_{2.5}$ and $\mathrm{PM}_{10}$ regulate the LAC concentrations depends on the relative contribution of different emission sources to a specific particulate matter fraction, since LAC is a fraction of these two. We observed a larger $\mathrm{M}_{\mathrm{LAC}} / \mathrm{PM}_{2.5}$ ratio at the kerbside stations than at the background sites and correlations were only strong for the rooftop site when the LRT event was considered. Thus, 
the use of $\mathrm{PM}_{2.5}$ as a proxy to estimate emission trends and projections of LAC concentrations should be used with caution.

To understand urban aerosol dynamics and long-term effects of aerosol particles on health, long continuous data sets are required. Thus, a longer field campaign should be conducted in a similar fashion in the Stockholm region. The new experiment might also allow studying the seasonal variation of the $\mathrm{M}_{\mathrm{LAC}}$ spatiotemporal distribution and how the contribution of the emission sources to the LAC content varies over the year. The possible contribution of residential wood combustion to the LAC fraction should be investigated in Stockholm in the wintertime.

Acknowledgements. This work was supported by the Swedish Environmental Protection Agency. The authors thank Hans Karlsson, Hans Areskoug, Leif Bäcklin at Stockholm University, and Billy Sjövall at the Environment and Health Protection Administration of Stockholm for their skilled assistance during the field campaign.

Edited by: P. Monks

\section{References}

Ackerman, A. S., Toon, O. B., Stevens, D. E., Heymsfield, A. J., Ramanathan, V., and Welton, E. J.: Reduction of tropical cloudiness by soot, Science, 288, 1042-1047, 2000.

Areskoug, H.: Measurements of $\mathrm{PM}_{10}-\mathrm{A}$ comparison of the most common methods used in Sweden with the European reference method (Bestämning av $\mathrm{PM}_{10}$ - En jämförelse av de vanligaste mätmetoderna använda i Sverige och den europeiska referensmetoden, only in Swedish), ITM report 168, Stockholm University, Stockholm, Sweden, 2007.

Areskoug, H., Johansson, C., Alesand, T., Hedberg, E., Ekengrena, T., Vesely, V., Wideqvist, U., and Hansson, H.-C.: Concentrations and sources of $\mathrm{PM}_{10}$ and $\mathrm{PM}_{2.5}$ in Sweden, ITM report 110, Stockholm University, Stockholm, Sweden, 2004.

Birch, M. E., and Cary, R. A.: Elemental carbon-based method for monitoring occupational exposures to particulate diesel exhaust, Aerosol Sci. Tech., 25, 221-241, 1996.

Bond, T. C., and Bergstrom, R. W.: Light absorption by carbonaceous particles: An investigative review, Aerosol Sci. Tech., 40, 27-67, 2006.

Bond, T. C., Streets, D. G., Yarber, K. F., Nelson, S. M., Woo, J.H., and Klimont, Z.: A technology-based global inventory of black and organic carbon emissions from combustion, J. Geophys. Res., 109, D14203, doi:10.1029/2003JD003697, 2004.

Burman, L. and Johansson, C.: : Emissions and concentrations of nitrogen oxides and nitrogen dioxide on Hornsgatan street; Evaluation of traffic measurements during autumn 2009 (Utsläpp och halter av kväveoxider och kvävedioxid på Hornsgatan analys av trafikmätningar under hösten 2009, in Swedish only), SLB report 7 http://slb.nu/slb/rapporter/pdf8/slb2010_007.pdf, last access: August 2011, 2010.

Cozic, J., Verheggen, B., Weingartner, E., Crosier, J., Bower, K. N., Flynn, M., Coe, H., Henning, S., Steinbacher, M., Henne, S., Collaud Coen, M., Petzold, A., and Baltensperger, U.: Chemi- cal composition of free tropospheric aerosol for $\mathrm{PM}_{1}$ and coarse mode at the high alpine site Jungfraujoch, Atmos. Chem. Phys., 8, 407-423, doi:10.5194/acp-8-407-2008, 2008.

Franco Suglia, S., Gryparis, A., Wright, R. O., Schwartz, J., and Wright, R. J.: Association of black carbon with cognition among children in a prospective birth cohort study, Am. J. Epidemiol., 167, 280-286, 2007.

Gidhagen, L., Johansson, C., Langner, J., and Olivares, G.: Simulation of $\mathrm{NO}_{\mathrm{x}}$ and ultrafine particles in a street canyon in Stockholm, Sweden, Atmos. Environ., 38, 2029-2044, 2004a.

Gidhagen, L., Johansson, C., Omstedt, G., Langner, J., and Olivares, G.: Model simulations of $\mathrm{NO}_{\mathrm{x}}$ and ultrafine particles close to a Swedish highway, Environ. Sci. Technol., 38, 6730-6740, 2004b.

Gidhagen, L., Johansson, C., Langner, J., and Foltescu, V.: Urban scale modeling of particle number concentration in Stockholm, Atmos. Environ., 39, 1711-1725, 2005.

Intergovernmental Panel on Climate Change (IPCC): Climate change 2001: the scientific basis, edited by: Houghton, J. T., Ding, Y., Griggs, D. J., Noguer, M., van der Linden, P. J., Dai, X., Maskell, K., and Johnson, C. A., Cambridge University Press, New York, USA, 572 pp., 2001.

Järvi, L., Junninen, H., Karppinen, A., Hillamo, R., Virkkula, A., Mäkelä, T., Pakkanen, T., and Kulmala, M.: Temporal variations in black carbon concentrations with different time scales in Helsinki during 1996-2005, Atmos. Chem. Phys., 8, 1017-1027, doi:10.5194/acp-8-1017-2008, 2008

Johansson, C., Norman, M., and Gidhagen, L.: Spatial and temporal variations of particle mass $\left(\mathrm{PM}_{10}\right)$ and particle number in urban air - Implications for health impact assessment, Environ. Monit. Assess., 127, 477-487, 2007a.

Johansson, C., Sjövall, B., Ferm, M., Karlsson, H., Vecely, V., Krecl, P., and Ström, J.: Relationship between $\mathrm{PM}_{10}, \mathrm{PM}_{1}$, and soot concentrations in Sweden (Relantionerna mellan halterna av $\mathrm{PM}_{10}, \mathrm{PM}_{1}$ och sot i Sverige, only in Swedish), ITM report 153, Stockholm University, Stockholm, Sweden, 2007b.

Johansson, C., Burman, L., and Forsberg, B.: The effects of congestions tax on air quality and health, Atmos. Environ., 43, 48434854, 2009.

Ketzel, M. Wåhlin, P., Kristensson, A., Swietilicki, E., Berkowicz, R., Nielsen, O. J., and Palmgrem, F.: Particle size distribution and particle mass measurements at urban, near-city and rural levels in the Copenhagen area and Southern Sweden, Atmos. Chem. Phys., 4, 281-292, doi:10.5194/acp-4-281-2004, 2004.

Kocbach, A., Johansen, B. V., Schwarze, P. E., and Namork, E.: Analytical electron microscopy of combustion particles: a comparison of vehicle exhaust and residential wood smoke, Sci. Tot. Environ., 346, 231-243, 2005.

Kondo, Y., Komazaki, Y., Miyazaki, Y., Moteki, N., Takegawa, N., Kodama, D., Deguchi, S., Nogami, M., Fukuda, M., Miyakawa, T., Morino, Y., Koike, M., Sakurai, H., and Ehara, K.: Temporal variations of elemental carbon in Tokyo, J. Geophys. Res., 111, D12205, doi:10.1029/2005JD006257, 2006.

Krecl, P., Ström, J., and Johansson, C.: Carbon content of atmospheric aerosols in a residential area during the wood combustion season in Sweden, Atmos. Environ., 41, 6974-6985, 2007.

Krecl, P., Johansson, C., and Ström, J.: Spatiotemporal variability of light-absorbing carbon concentration in a residential area impacted by woodsmoke, J. Air Waste Manage., 60, 356-368, 
2010.

Kupiainen, K. and Klimont, Z.: Primary emissions of fine carbonaceous particles in Europe, Atmos. Environ., 41, 2156-2170, 2007.

Lighty, J. S., Veranth, J. M., and Sarofim, A. F.: Combustion aerosols: factors governing their size and composition and implications to human health, J. Air Waste Manage., 50, 1565-1618, 2000.

Lin, C. I., Baker, M. B., and Charlson R. J.: Absorption coefficient of the atmospheric aerosol: a method for measurement, Appl. Opt., 12, 1356-1363, 1973.

Menon, S., Hansen, J., and Nazarenko, L.: Climate effects of black carbon aerosols in China and India, Science, 297, 2250-2253, 2002.

Naser, T. M., Kanda, I., Ohara, T., Sakamoto, K., Kobayashi, S., Nitta, H., and Nataami, T.: Analysis of traffic-related $\mathrm{NO}_{\mathrm{x}}$ and EC concentrations at various distances from major roads in Japan, Atmos. Environ., 43, 2379-2390, 2009.

Norman, M., and Johansson, C.: Studies of some measures to reduce road dust emissions from paved roads in Scandinavia, Atmos. Environ., 40, 6154-6164, 2006.

Olivares, G., Johansson, C., Ström. J., and Hansson, H.-C.: The role of ambient temperature for particle number concentrations in a street canyon, Atmos. Environ., 41, 2145-2155, 2007.

Pereira, S., Wagner, F., and Silva, A. M.: Scattering properties and mass concentration of local and long-range transported aerosols over the South Western Iberia Peninsula, Atmos. Environ., 42, 7623-7631, 2008.

Putaud, J.-P., Raes, F., Van Dingenen, R., Uggemann, E., Facchini, M.-C., Decesari, S., Fuzzi, S., Gehrig, R., Uglin, C. H., Laj, P., Lorbeer, G., Maenhaut, W., Mihalopoulos, N., Uller, K. M., Querol, X., Rodriguez, S., Schneider, J. U., Spindler, G., ten Brink, H., Tørseth, K., and Wiedensohler, A.: A European aerosol phenomenology-2: chemical characteristics of particulate matter at kerbside, urban, rural and background sites in Europe, Atmos. Environ., 38, 2579-2595, 2004.
Ramanathan, V. R., Crutzen, P. J., Kiehl, J. T., and Rosenfeld, D.: Aerosols, climate and the hydrological cycle, Science, 294, 2119-2124, 2001.

Ramanathan, V. R., Ramana, M. V., Roberts, G., Kim, D., Corrigan, C., Chung, C., and Winker, D.: Warning trends in Asia amplified by brown cloud solar absorption, Nature, 448, 575-579, 2007.

Sharma, S., Brook, J. R., Cachier, H., Chow, J., Gaudenzi, A., and Lu, G.: Light absorption and thermal measurements of black carbon in different regions of Canada, J. Geophys. Res., 107, 4771, doi:10.1029/2002JD002496, 2002.

Streets, D. G., Bond, T. C., Lee, T., and Jang, C.: On the future of carbonaceous aerosol emissions, J. Geophys. Res., 109, D24212, doi:10.1029/2004JD004902, 2004.

Targino, A. C., Krecl, P., Johansson, C., Coraiola, G., Swietlicki, E., Massling, A., and Lihavainen, H.: Deterioration of air quality across Sweden due to transboundary agricultural burning emissions, Atmos. Environ., in review, 2011.

Venkatachari, P., Zhou, L., Hopke, P. K., Felton, D., Rattigan, O. V., Schwab, J. J., and Demerjian, K. L.: Spatial and temporal variability of black carbon in New York City, J. Geophys. Res., 111, D10S05, doi:10.1029/2005JD006314, 2006.

Wilson, J. G., Kingham, S., Pearce, J., and Sturman, A. P.: A review of intraurban variations in particulate air pollution: Implications for epidemiological research, Atmos. Environ., 39, 6444-6462, 2005.

Wongphatarakul, V., Friedlander, S. K., and Pinto, J. P.: A comparative study of $\mathrm{PM}_{2.5}$ ambient aerosol chemical databases, Environ. Sci. Technol., 32, 3926-3934, 1998. 